УДК: 37.035:916

Olatunji OYESHILE

University of Ibadan, Nigeria

alabi14@yahoo.com

\title{
EDUCATION AS TEMPLATE FOR EXISTENTIAL IMPERATIVES AND SOCIAL ORDER IN AFRICA
}

The pivotal role which education plays in helping humanity to come to terms with existential imperatives

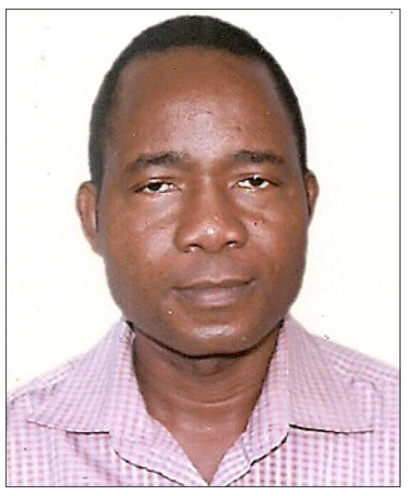
cannot be over emphasized. It is the management of the flux concomitant to existential imperatives that can ensure social order, understood in normative perspective. In this paper, I address the development and conception of education within the African continent, particularly Nigeria and argue that the foundation of education must be predicted on humane values which the humanities, other than the natural sciences in spite of their utilitarian values, provide. Furthermore, I argue that given the humanistic basis of education predicated on certain human and communal values, existential predicaments can be addressed thereby paving way for social order and by extension human happiness which is the goal of development in any part of the world. The paper concludes that government is the greatest teacher and the actions and inactions of government, as the sustainer of right values, in Africa matter more in ensuring development-oriented education that can adequately combat our existential challenges as well as ensure the entrenchment of social order for sustainable development.

Keywords: Education, Existential imperatives, Social order, Values, Africa.

\section{I \\ Introduction}

"All serious discussion of educational problems, no matter how specific, soon leads to a consideration of educational aims, and becomes a conversation about the good life, the nature of man, the varieties of experiences"

(Max Black, 1969:11).

There is no gainsaying the fact that education is central to the holistic development of man and society. Whether as black people, white people or colour of any sort, we all need education not only to adapt to our being-in-the-world, as result of what Martin Heidegger regards as our 'fallenness', but also to organize our flux of experience in order to survive and live a happy life, which I think constitutes the essence of human life. However, going by the insight- 
ful excerpt above from Max Black (1969:11), there are concomitant problems which form the content of education in its various dimensions and juxtapositions and which also indicate that the drive towards the 'essence' of life which is happiness cannot be attained unless the existential dimension of human life is given adequate attention. It is therefore, not surprising that for most of us, who are self-professed existentialists, "existence" precedes essence" (See Sartre, 1958; 1976). The reason for these proclamations would be clear to us as this paper progresses but suffice to note at the outset, as my title implies, education constitutes the main basis for addressing our existential imperatives and the ability to establish this intervention of education in our existential sphere will certainly help to address our quest for social order which is the foundation for development, especially sustainable development not only in Nigeria but in most part of Africa.

\section{II \\ Education and the Quest for Knowledge}

I want to start by noting that the major aim of education is knowledge. The type of education a person acquires also determines the kind of knowledge one has. In this regard, we can talk about technical education, moral education, political education, and scientific education among others. Knowledge on the other hand can be for two major purposes. First is knowledge for its own sake, that is, the intrinsic knowledge, and secondly, knowledge for the sake of other things, and this is the extrinsic dimension of knowledge. The quiddity of any type of education lies in the attainment of sustainable development and human happiness.

According to Chambers $20^{\text {h }}$ Century Dictionary, education means 'bringing up or training, as of a child: instruction; strengthening of the powers of body or mind; culture (chambers, 1983; 398). Plato introduced the moral dimension of education by describing it as;

The training which is given by suitable habits to the first instincts of virtue in children when pleasure and pain are rightly implanted in non-rational souls. The particular training in respect of pleasure and pain, which leads you to hate and love what you ought to hate and love is called education (Plato in Schofield, 1972:31).

We are not surprised about the moral dimension from which Plato defined education because, like his master, Socrates, his aim was how to achieve the good life. This goal even formed the basis of his Republic in which members of the guardian class are to be given sound moral education in preparation for the future governance of the Athenian society. With all sense of hindsight, I can also say that the traditional African societies gave priority to moral educa- 
tion made up of various values over other forms of education. Still on Plato, we could also see that what differentiates the guardian class from the auxiliary (soldier) and producer classes is the moral education which serves as the basis for other kinds of education such as combative and agricultural education.

Milton takes a step ahead of Plato by looking at education from the utilitarian perspective. He says: I call, therefore, a complete and generous education that which fits a man to perform justly, skillfully and magnanimously all the offices, both public and private of peace and war (Milton cited in Schofield, 1972:31).

The definition by Milton seems to encompass the moral, technical and socio-political aspects of human life. It also presupposes that an educated person should have knowledge about all spheres of human endeavor. Of course, this is a tall dream. Etymologically however, education is from educare (Latin root). This means to form or train. Among the various schools of thought in education are the formalists and the naturalists (Schofield, 1972:32). The formalists believe that education is a discipline and that children learn what is good for them. The children are seen but not heard and are made into a specific people by their education. The naturalists on the other hand believe that education should merely 'let the child develop'. The three definitions of education from the Chambers' perspective, Plato and Milton all suggest the need for training, the ability to be able to acquire certain skills, technical and political and the need to apply the skills so acquired in the development of society. This would mean by inference that education must imply the transmission of what is worthwhile and we should not be oblivious of the fact that culture or society determines most of what is worthwhile. Perhaps, this is why Max Black suggested that all serious discussion of educational problems invariably involves the consideration of education aims and a conversation about the good life, the nature of man and the varieties of experiences.

In spite of our utilitarian conception and the role of culture in shaping such education, Alfred North Whitehead notes that whatever ideas are received by the child, it is important that he makes them his own and should realize how such ideas apply to the situations of his own life (Curtis and Boultwood, 1977: 537). In this vein, whitehead writes: From the very beginning of his education, the child should experience the joy of discovery. The discovery which he has to make is that general ideas give an understanding of that stream of events which pours through his life, which is his life (Whitehead cited by Curtis and Boultwood, 1977: 537).

It this based on the perspective above that whitehead defines education as the acquisition of the art of utilization of knowledge (Curtis and Boultwood, 1977: 537). Given the foregoing, it then easy to appreciate the burdens of philosophers and philosophers education in coming to terms with not only educa- 
tion and the quest for, and utilization of knowledge but also the concerns with man who occupies a central position in ensuring that education is not only beneficial to man himself but to his culture and society.

III

\section{Existential Imperatives}

Education is a major intervention in the absurdity of human existence. What are some of the features of this absurd nature of human life? They include the irrational nature of the world, facticity of human existence, want, anxiety, anguish, the quest for freedom and authenticity, bad faith, the existence of others, nothingness and death among others. The existentialist philosophers have concentrated every of their effort in the quest for man to live within the absurd world.

As human beings we are, first and foremost, occupied with the issues of survival and existence. These issues constitute in one way or the other our existential imperatives. We make attempts in various directions, whether systematic or unsystematic but often consciously to see to the realization of our goals. In his classic work, The Myth of Sisyphus (1955), Albert Camus paints the problem thus: There is but one truly serious philosophical problem and that is suicide. Judging whether life is or is not worth living amounts to answering the fundamental question of philosophy. All the rest- whether or not the world has three dimensions, whether the mind has mine or twelve categories - come afterwards. Whether the earth or the sum revolves around the other is a matter of profound indifference. To tell the truth, it is a futile question. I have never seen anyone die for the ontological arguments. On the other hand I see many people die because they judge that life is not worth living. I therefore conclude that the meaning of life is the most urgent of questions (Camus, 1955:11 - 12).

The problem of the question of meaning of life, if not addressed, will often lead to suicide as Camus suggests. This same quest is described in various ways by other existentialist philosophers as we shall see very soon. Let us note that when one considers the logical relationship between the words "life" and "struggle", it will be discerned that the relationship is symmetrical (Oyeshile, 1995:12). This means that it is proper to say that life depends on the struggle one puts into it. Conversely, it is equally true that struggle depends on life. After all, a person has to live before he can struggle. Invariably, the two concepts are inseparable. By the time one jettisons any of both cognate terms, then one is as good as dead. Struggle is deciphered by many as a means towards a permanent end.

Given the existential imperatives of man as construed by the existentialists, we can then begin to see the need for education in helping to organize man's 
flux of experience. Based on this, we can appreciate why Omatseye (2003), titled his inaugural thus: Philosophizing an the Enigma called man: Does education really matter? According to Omatseye the unfolding scenario of history often reveals the enigmatic nature of man whose essence is polarized severally. This enigmatic nature of man could play out in man being "God like and beastlike, exalted and base, free and enslaved, adapted for rising and failing, capable of great love and sacrifice, capable of cruelty and unlimited egoism" (Berdyaev being cited by Omatseye, 2003:2). Furthermore, inspite of the negativities of man, "man is still one animal that is endowed with the ability to reason, use symbols, develop abstractions, intend and imagine something that is far in distance and time" (Omatseye, 2003:2).

Encapsulated in the preceding comments from Omatseye is what can be regarded as a clear expression of human nature which is the sense of insecurity or fear of the unknown. How then do we tackle this phenomenon and give a sense of order to man? Omatseye provides the answer by understanding the importance of education when he avers thus: "Although one's sense of insecurity may vary with his situation in life-be it social, economic, cultural etcetera- his level of education and state of mind are a key factor in how he handles his life challenges" (Omatseye, 2003;7).

In a similar vein, Ayodele - Bamisaye (2009) submits that: Man is therefore by nature endowed to be educable.... to good old Plato in the area of ethics and education to say that man should be educated in order for him to be of value to himself and to humanity. Human value.... is not just in his knowledge acquired, it is the disposition to use knowledge for construction rather than for destruction, for self and social advancement rather than for self-advancement at the expense of social well-being (Ayodele - Bamisaiye, 2009:65).

It is note-worthy that education has a very central role in organizing the existential imperatives of man.

\section{IV \\ Social Order in Africa}

The fact cannot be controverted that human life is replete with absurdities, and this makes the intervention of education a sine qua non. But it is pathetic to note that the problem of social order in Africa has complicated the role of education in the management of these absurdities. It is also the case that while social order affects education, education can also affect social order. Rational individuals will prefer a society in which there is order as against a society in which there is disorder. This is because it is in state of social order that an individual can carry out his projects and realize his goals, goals which provide the necessary conditions for the attainment of the happy life which Aristotle refers 
to as the highest good, the summum bonum (Mckeon, 1947). African are not an exception in this regard. Although no human society is perfectly insulated against social disorder in its various manifestations, due to certain peculiar traits of human nature, which Hobbes refers to as 'instincts of self-preservation', our experience in Africa depicts a continually retrogressing society where most moral values, necessary for the sustenance of the modern state, have been bastardized and compromised due to a plethora of reasons.

A cursory but critical look at our African society shows that the social order necessary for the anchoring of development is lacking. This can be seen when we look at various areas of human endearvour. Our use of social order in this context must be properly defined. Social order can be taken to mean: first, the arrangement or state of things in the society; second, the proper functioning of societal institution; and third, political stability. It is the second and third perspectives that are emphasized in this context. In a broad sense, the concept of 'social order' is used to refer to the harmonious functioning of different facets of a society such as the political, economic, educational, religious, scientific and technological institutions. It is through the harmonious functioning of these different institutions that there can be development in any human society (Oyeshile, 2004:295).

What are some of the underlying factors that have contributed to the social crisis in Africa, which is mired in civil wars, poverty, disease, illiteracy, child labour, corruption, political ineptitude and economic disintegration and disorientation? The economic, political and religious spheres easily come to mind. Vices such as corruption, bad leadership, election rigging, fraud in public offices, inequitable distribution of national resources and many others have been the albatross around the neck of African development.

Irrespective of one's religious, ethnic and political leanings, human existence itself is punctuated with problems of various natures which we grapple with from time to time. However, for many societies in which there is a manageable sense of social order, the resolution of one set of problems normally improves their fortunes, especially as often reflected in their socio-economic learning. A similar thing cannot be said about many countries in Africa. What we experience in Africa concerning the socio-political order leaves much to be desired. Let us visualize, for instance, the Liberia conflict until the installment of the current female president in 2006, where there was a free for all killing over political ascendency coupled with the illegal trade in diamonds that further escalated the conflict situation in Sierra Leone and the Great Lake region of the Congo Democratic Republic; Uganda, Rwanda and Burundi. Notable names like Idi Amin Dada, Mobutu Sese Seko, Charles Taylor, Emperor Bokassa and Sanni Abacha come to mind not because of their ability to liberate their people and put them on a secure path to development but because 
they have decimated the human and material resources of their nations leaving these nations poorer and more unstable than they met them. Somalia remains a failed state while recent violence in Nigeria due to the terrorist activities of Boko Haram members have almost paralyzed governance in the northern part of Nigeria.

However, it must be noted that some sense of social order still prevails in countries like Senegal, Ghana, Botswana and South Africa. In South Africa, the Blacks and the Whites were easily reconciled by President Nelson Mandela especially through the Truth Reconciliation Committee. Within two decades of majority black rule in South Africa, the country has become a showcase for the rest of the world indicating that things can work properly in Africa. We cannot but give kudos to South Africa's great leaders like Nelson Mandela, De Klerk, Bishop Desmond Tutu, Thabo Mbeki and many others who have put the public good above their own individual interests and aggrandizement.

\section{$\mathbf{V}$
What type of Education?}

The main issue here has to do with the type of education that will be the basis of social order thereby leading to sustainable development in our society. Education, as it is generally deciphered, is the key to real regeneration and meaningful development and a crucial tool for social transformation. And according to Nduka, education is the most sensitive instrument not only for effecting but also for monitoring progress in the realization of the nation's goals and objectives, education helps individuals to acquire literacy and technical know-how and constitutes the vehicle for the diffusion of culture and ideas (Nduka, 2006).

If our pre-suppositions about education above are anything to reckon with, what has been the state of education in Nigeria, a country which deeply reflects many parts of the African experience?. We have to take off from the challenges confronting education from the primary level of education to the tertiary level. At both the primary and secondary levels, the major problems of funding, expertise, curriculum, commitment and the problem of language have been the recurring issues to which numerous education experts have produced numerous books. Yet we cannot say that all is well at these levels. The most pathetic aspect of these problems is that the primary and secondary levels of education determine the quality of product at the tertiary level. The major tragedy however is that people have almost lost confidence in the public schools thereby leaving an important sector of human development in the hands of private proprietors. The tertiary education is almost suffering similar fate with the neglect of public polytechnics and universities. 
The urge to promote scientific and technological development became an inescapable one for most African countries, especially Nigeria in the third quarter of the $20^{\text {th }}$ century. This prompted the Nigerian government in the 1980s to adopt a policy which favours the increase enrolment of science related courses to the disadvantage of the humanities-based disciplines on $60 \%$ to $40 \%$ basis. This policy almost led to the strangulation of the humanistic disciplines which provided the value orientation for education. Yet we cannot say that 37 years after, this policy has led to break through much needed in science and technology.

While nobody can contest the claim that science and technology constitute a very important basis for the development of man, neglecting the humanistic education is counterproductive to the development of science and technology. The reason for this is not far-fetched.

According to Abiola Irele: What we now recognize as the scientific spirit is the product of a whole movement of ideas by which what we now refer to as the West sought to understand man and the universe; the ground for modern science was a matter of historical fact prepared by the development of Western Philosophy (Irele, 1982:26).

The emphasis above is that development in science and technology needs to be well grounded on a system of ideas which, for now, is absent in Africa. The West got to this present enviable stage of scientific development, because their value system was grounded in philosophical and other general ideas that are conducive to the emergence of a scientific and technological culture.

A major importance of education in the humanities lies in the fact that it satisfies certain needs of man which are beyond the physical and material needs which science and technology are concerned with. According to Sogolo: The satisfaction of such needs is beyond the reach of science because these have to do with phenomena which are not explicable in terms of some laws of natural processes. The sciences seek, through the formulation of law and theories, to create order and uniformity out of apparent diversity, to apply such laws in adapting the environment to suit man's needs. Paradoxically, however, in doing all this for man, science seems to stand indifferent to the fate of this very object it purports to serve. This aspect, according to the history of education, has long been assigned to the humanities (Sogolo, 1981:111-112).

We can apply the inferences above on the role of science and humanistic education to African development by noting that development itself is a complex, multi-faceted enterprise. Oladipo puts this succinctly when he writes: The problem of development is a complex, many-sided problem. True, it has a technical side which we can tackle by developing the appropriate scientific and technical education for our people. It also involves the search for abiding values 
in terms of which we can make sense of our experiences and develop the right kind of attitudes in our society and its institutions (Oladipo, 1999:118).

The import of the above is that the Nigerian system of higher education should be understood in the context of society and culture. Although one is a firm believer in science education, moral and cultural education which the humanities champion is a basis for development. Hence, educational curricula should be framed given this in mind. Perhaps what we have been trying to establish is that contemporary educational orientation lacks the human and cultural value basis, the absence of which social order and by extension, sustainable development cannot be achieved. Let me also touch briefly on some other issues that border on values in our educational sphere especially at the tertiary level, which I believe would have been discussed extensively by other scholars.

\section{VI \\ Conclusion: Education Predicated on Values}

Having identified the problem of values (which we often neglect) in our educational orientation from various perspectives such as in educational curriculum from primary to tertiary levels, in the promotion of science and technology, in education's materialization and commercialization, in intellectual terrorism and disappearing academic culture and the values attributed to our certificates, it becomes pertinent to suggest some ways in which we can overcome this crisis of education that has sometimes resulted in unending antagonism and agonism between government and academic unions at all levels of our education.

My template for resolving this crisis is predicated on human and communal values. And the application of these values cuts across all the stakeholders in the society. The central argument is that if we embrace certain values not as a matter of formality but substantially and we create a better society then most of our problems, of which the crisis of education is a part, will be fixed. The values help in coping with existential imperatives and thereby helping to address the problem of social order in all guises. The stability of education sphere is tied to socio-political order. And when the problem of social order is fixed, we can then experience sustainable development which will guarantee human happiness and meaningful life while we prepare towards our ultimate end, death, which limits all human possibilities.

Let us once again remind ourselves of some of the causes of social disorder and political crisis. These include problem of leadership, followership, ethnicity, religious intolerance, unstable democratic governance with its attendant injustice and corruption, unbridled poverty on the part of the majority, unparalleled opulence for the few and lack of political education. We do not need 
any extensive explanation of these maladies since Africans live with them on daily basis and more than a considerable literature has been devoted to them. However, the root of all these problems can be traced to a dearth of certain enduring social-ethical/communal values in contemporary society, which has made us to give little consideration to the concept of humanity that all ethical values champion.

The crux of our problem, which has made the educational sphere and other spheres inadequate to addressing our myriad of problems, is governance erected on leadership ineptitude. Our leaders only pay lip service to human and communal values because they do not reflect these values in their action and more often than not the citizens learn from them not to keep rules, agreements and to be unjust. In most cases we do not have leadership by example.

Let us again take democracy as one of such human values. The beauty and functionality of democracy lies with its features and principles such as rule following, accountability, popular participation, protection of human right, equitable resource distribution, and freedom to determine who exercises sovereignty on one's behalf. These features constitute the hallmark of truly democratic governments all over the world. It is therefore not the tag- democracy - that makes a government democratic but the conformity and adherence to democratic principles. What we find in most part of Africa is that leaders do not respect and follow democratic principles and so the problem of social order is compounded from time to time.

In order to sustain democratic governance, which is the first step towards social order and subsequently development, African leaders must exhibit democratic spirit, which involves being inundated with the rules, features and attributes of democracy that in themselves are not ends but means to a viable political order in which the individuals can have a conducive social and political space to actualize their desires in any area of human endeavor including education. It is through the democratic spirit that African leaders can understand the purpose of governance, construed mainly as the pursuit of public interest (Oyeshile, 2011:239).

It is only when the problem of leadership in most African countries is fixed that we can start to experience social order in all facets of life, and this will enhance sustainable development. We learn and develop these values that will enhance social order through education, and the attainment of a stable social order provides the needed support for education. It is when leaders abide by these values in their actions that these values are automatically learnt and they become part and parcel of the society. We can only get our education right if our leaders who are our public teachers conform to rules and regulations and do things right, irrespective of the situation they find themselves. This will invariably engender social order and when there is social order, development is 
accelerated and sustainable development is attained. We certainly do not deserve less from our leaders.

Let me at this juncture recap my major arguments. Education has a vital role to play in making man to cope with existential imperatives. The existential imperatives in Africa are compounded by the problem of social order. We therefore need to fix the problem of social order to allow education to play its role and enhance development. To fix the problem of social order, I recommended the revitalization of human and communal values and stressed the need that our leaders should abide by these values so that they can be better mirror from which the society will learn and be educated to do things right. If things are done right, we can also fix other problems arising from education and other institutions in society.

\section{References:}

1. Ayodele - Bamisaiye, O. (2009) What is Man, That we Should Educate him? University Lecture. University of Ibadan.

2. Black, M. (1969) "Note on Philosophy of Education" in C.J. Lucas (ed.), What is Philosophy of Education? London: Macmillan.

3. Camus, A. (1955) The Myth of Sisyphus. Middlesex: Penguin Books.

4. Chambers $20^{\text {th }}$ Century Dictionary. (1983) E.M. Kirkpatrick (ed.) Edimburg: W\&R Chambers Ltd.

5. Curtis, S.J. \& Boultwood, M.E.A. (1977) A Short History of Educational Ideas. Fifth Edition. Surrey University Tutorial Press Ltd.

6. Irele (1982) In Praise of Alienation. An Inaugural Lecture. University of Ibadan November.

7. Mckeon, R.. (ed.) (1947) Introduction to Aristotle. New York: The Modern Library.

8. Nduka, O. (2006) The Roots of African Underdevelopment and other Essays. Ibadan; Spectrum Books Ltd.

9. Oladipo, O. (1999) Beyond Survival: Essays on the Nigerian Condition. Ibadan: Hope Publications.

10. Omatseye, J.N. (2003) Philosophizing on the Enigma called Man: Does Education Really Matter? An Inaugural Lecture: University of Benin.

11. Oyeshile, O. (1995) “The Paradox of Struggle”. The OBSERVER. Thursday August, 31.

12. Oyeshile, O.A. (2004) "Communal values, Cultural Identity and the challenge of Development in Contemporary Africa”. Journal of Social, Political and Economic Studies, Vol. 29, No. 3 (fall).

13. Oyeshile, O.A. (2011) "Sen's Realization- Focused Notion of Justice and the Burden of Democratic Governance in African Societies", Indian Journal of Human Development, Vol. 5, No. 1 (January - June).

14. Sartre, J.P. (1958) Being and Nothingness. Translated by Hazel E. Barnes, Introduction by Mary Warnock. London: Methuen and Co. Ltd.

15. Sartre, J.P. (1976) "Existentialism is a Humanism" Reproduced in Alburey Castell (ed.), An Introduction to Modern Philosophy, $3^{\text {rd }}$ Edition. New York: Macmillan. 
16. Schofield, H. (1972) The Philosophy of Education; An Introduction. London: George Allen and Unwin Ltd.

17. Sogolo, G. (1981) "Literary values and the Academic Mind: A Portrait of the Humanistic Studies", Ibadan Journal of Humanistic Studies, No. 2. (October).

18. Whitehead, A.N. (1964) The Adventures of Ideas. Cambridge: University Press.

\section{Олатуньї А. Уйшайл. Освіта як модель екзистенціальних імперативів та соціального порядку в Африці ${ }^{1}$}

Ключову роль, яку відіграє освіта в тому, щоб допомогти людству дійти згоди щодо екзистенційних імперативів, неможливо переоцінити. Тільки управління життєвим потоком відповідно до екзистенційних імперативів може забезпечити соціальний порядок, який розуміється 3 нормативної точки зору. У даній статті я розглядаю розвиток і концепцію освіти на африканському континенті, зокрема, в Нігерії, і стверджую, що основа освіти повинна передбачати гуманістичні цінності, які забезпечують гуманітарні науки, на відміну від природничих наук, незважаючи на їх утилітарну цінність. Крім того, я стверджую, що, з огляду на гуманістичну основу освіти, що передбачає певні особистісні та колективні цінності, екзистенційні проблеми можуть бути вирішені за допомогою руху шляхом до соціального порядку і за допомогою поширення людського щастя, що є метою розвитку в будь-якій частині світу. У статті робиться висновок, що уряд є найбільшим учителем, а дії або бездіяльність уряду як носія правильних цінностей в Африці мають велике значення для забезпечення освіти, орієнтованої на розвиток, яка може адекватно сприяти боротьбі з нашими екзистенційними проблемами, а також зміцненню соціального порядку для сталого розвитку.

Ключові слова: освіта, екзистенційні імперативи, соціальний порядок, цінності, Африка.

\section{Олатуньи А. Уйшайл. Образование как модель экзистенциальных импера- тивов и социального порядка в Африке}

Ключевую роль, которую играет образование в том, чтобы помочь человечеству прийти к согласию с экзистенциальными императивами, невозможно переоценить. Только управление жизненным потоком в соответствии с экзистенциальными императивами может обеспечить социальный порядок, понимаемый с нормативной точки зрения. В данной статье я рассматриваю развитие и концепцию образования на африканском континенте, в частности, в Нигерии, и утверждаю, что основа образования должна предусматривать гуманистические ценности, которые обеспечивают гуманитарные науки, в отличие от естественных наук, несмотря на их утилитарную ценность. Кроме того, я утверждаю, что, учитывая гуманистическую основу образования, предусматривающую определенные индивидуальные и коллективные ценности, экзистенциальные трудности

\footnotetext{
${ }^{1}$ Переклад з англійської Л.Горбунової.
} 
могут быть преодолены с помощью движения по пути к социальному порядку и посредством распространения человеческого счастья, что является целью развития в любой части мира. В статье делается вывод, что правительство является самым большим учителем, а действия или бездействие правительства как носителя правильных ценностей в Африке имеют большое значение для обеспечения образования, ориентированного на развитие, которое может адекватно разрешать наши экзистенциальные проблемы, а также способствовать укреплению социального порядка для устойчивого развития

Ключевые слова: образование, экзистенциальные императивы, социальный порядок, ценности, Африка.

Olatunji A. Oyeshile, Ph.D, Professor, Department of Philosophy, University of Ibadan, Ibadan, Nigeria. E- mail: alabi14@yahoo.com

Oyeshile specializes in African Philosophy (with emphasis on IndividualCommunity Relationship) Metaphysics and Existentialism. He is an editorial consultant to Philosophia (The Philippines). He has about 65 publications in books and journals and he is co-editor of The Idea of a Nigerian University: A Revisit. Nigerian Philosophical Studies III. Washington D.C: The Council for Research in Values and Philosophy, 2013. He is a member of International Society for Universal Dialogue (ISUD). He is co-editor of Ethics, Governance and Social Order in Africa: Essays in Honour of Godwin S. Sogolo. Ibadan Zenith Book House Ltd. 2016.

Олатуньї А. Уйшайл, доктор філософії, професор кафедри філософії Ібаданського університету, Нігерія.

Уйшайл є фахівцем з африканської філософії (з акцентом на відносини між індивідом і суспільством), метафізики та екзистенціалізму. Він $є$ консультантом редакції журналу «Філософія» (Філіппіни), співредактором книги «Ідея нігерійського університету: повернення» / Нігерійські філософські дослідження III. Вашингтон: Рада з досліджень в області цінностей і філософії, 2013; членом Міжнародного Товариства Універсального Діалогу (ISUD); співредактором книги «Етика, управління і соціальний порядок у Африці: нариси, присвячені Годвіну С. Соголо». Ібадан, Зеніт Бук Хауз, 2016. 